Int. J. Electrochem. Sci., 14 (2019) 3035 - 3054

International Journal of

ELECTROCHEMICAL

SCIENCE

WWw.electrochemsci.org

\title{
Electrochemical Performance of Porous Ni-Cu Anodes for Direct Methanol Fuel Cells
}

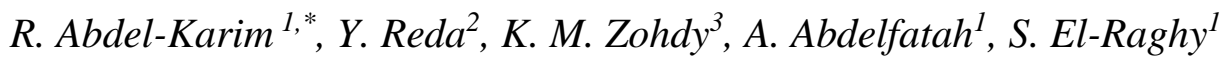 \\ ${ }^{1}$ Corr. and Surface Treatment Lab., Dept. of Metallurgy \\ Faculty of Engineering- Cairo University, Giza 12613, Egypt. \\ ${ }^{2}$ Chemical Engineering Department, Higher Institute of Engineering and Technology, New Damietta \\ 34517, Egypt. \\ ${ }^{3}$ Higher Technological Institute, $10^{\text {th }}$ of Ramadan city, Egypt \\ *E-mail: randaabdelkarim@gmail.com
}

doi; $10.20964 / 2019.03 .59$

Received: 30 October 2018 / Accepted: 21 December 2018 / Published: 7 February 2019

\begin{abstract}
Transition metal 3D porous foams based on $\mathrm{Ni}$ and $\mathrm{Cu}$ were prepared using Hydrogen Bubble Dynamic Template "DHBT" technique, from an acidic solution containing $\mathrm{Ni}-\mathrm{Cu}$ salts as a source for Ni-Cu deposits. The morphology of the deposited films was affected by the current density and deposition time. At low current density and short deposition time $(30 \mathrm{sec})$, smooth films composed of angular grains, with few randomly distributed isolated dendrites were detected. At high current density, typical ramified dendritic morphology was developed. The Ni content of the deposited layer varied from 68.49- 87.86 $\%$. The electrocatalytic behavior of these layers was evaluated using potentiodynamic, cyclic voltammetry and electrochemical impedance test in acidic $1 \mathrm{M}$ methanol solution. From potentiodynamic test results, increasing the deposition current density as well as deposition time lead to more anodic and current density, reflecting high electro catalytic behavior towards methanol oxidation. In addition, the forward peak intensity and total charge measured by cyclic voltammetry increased under the effect of higher applied current density and longer deposition time having a positive effect on the electrochemical activity of the Ni-Cu NPMFs deposited. According to EIS data, the charge transfer resistance $\left(R_{p}\right)$ decreased as the current density as well as electrodeposition time increased. The lowest polarization resistance $(51.7 \Omega)$ required for high electrocatalytic behavior was detected for porous $\mathrm{Ni}$ $\mathrm{Cu}$ layers electrodeposited at $2 \mathrm{Amp} / \mathrm{cm}^{2}$ and deposition time $150 \mathrm{sec}$.
\end{abstract}

Keywords: Fuel cells; Ni-Cu deposits; Dynamic Hydrogen template; SEM; Ramified Dendrites; Potentiodynamic test ; Cyclic voltammetry; EIS.

\section{FULL TEXT}


(C) 2019 The Authors. Published by ESG (www.electrochemsci.org). This article is an open access article distributed under the terms and conditions of the Creative Commons Attribution license (http://creativecommons.org/licenses/by/4.0/). 